\title{
THE USE AND IMPLICATIONS OF MANAGEMENT ACCOUNTING PRACTICES IN SMALL AND MEDIUM-SIZED ENTERPRISES
}

\author{
Zaid Jaradat ${ }^{*}$, Roshaiza Taha ${ }^{2}$, Rosliza Mat Zin ${ }^{3}$, \\ Wan Zuriati Wan Zakaria ${ }^{4}$ and Rozainun Abdul Aziz \\ ${ }^{1}$ Accounting Department, Faculty of Business, Al-Zaytoonah University of Jordan, Jordan. \\ ${ }^{2,3,4}$ School of Maritime Business and Management, \\ University Malaysia Terengganu, Terengganu, Malaysia. \\ ${ }^{5}$ Faculty of Accountancy, Universiti Teknologi MARA, Malaysia.
}

\begin{abstract}
Management Accounting Practices (MAPs) usage among Small and Medium-sized Enterprises (SMEs) and their implications are examined in this paper. 291 sets of questionnaires were dispersed and six interviews were conducted to gather the data. The usage frequency of individual practices and thematic analysis are deliberated, and the results denote the comparatively low MAPs usage rates among Jordanian SMEs as opposed to those in developed countries. Nonetheless, the reported rates in Jordan are comparable to those in developing countries. Among SMEs, MAPs significantly allow product cost information determination, planning and controlling, and detection of problems. Shortcomings of the traditional system, previous experiments of large companies, and external factors, are considered as the main reasons that motivated SMEs to use MAPs. Insufficient experience, lack of financial resources, and the high costs associated with implementing MAPs are the most crucial reasons that forced SMEs to neglect to use a lot of MAPs. The present study enriches the knowledge of MAPs in the context of SMEs. Also, the significance of MAPs among SME managers is highlighted. Equally, this study should stimulate additional scrutiny and analysis of MAPs amongst SMEs.
\end{abstract}

Keywords: management accounting practices (MAPs), small and mediumsized enterprises (SMEs), Jordan, diffusion of innovations theory

\section{ARTICLE INFO}

Article History:

Received: 1 February 2020

Accepted: 12 March 2021

Published: 30 April 2021

* Corresponding Author: Zaid Jaradat. E-mail: z.jaradat@zuj.edu.jo 


\section{INTRODUCTION}

Researchers in many fields associated with business management and economics have been showing significant interest in Small and Mediumsized Enterprises (SMEs). SMEs are major contributors in the alleviation of poverty as they provide jobs and income to the people and for this reason, some (e.g., Bruque \& Moyano, 2007; Dogan et al., 2017; Günerergin et al., 2012; Lee et al., 2015; Okpara, 2011; Wang et al., 2018), SMEs have been viewed as the engine of economic development.

SMEs in Jordan represent nearly the entire manufacturing sector, at $98 \%$ (JCI, 2015). Meanwhile, the manufacturing sector has been consistently supporting the Jordanian foreign currency reserves with over $\$ 8$ billion yearly, and for this reason, this sector significantly promotes the Jordanian dinar exchange rate. Further, this sector has a market share that takes up $60 \%$ of the total investments from the investment laws. Besides, by its endowment of more than $\$ 1.4$ billion to the treasury every year through direct and indirect taxes, the manufacturing sector boosts the financial stability of the country.

As manufacturing firms are integral to the development and expansion of any developing economy, there has to be a mechanism for the maintenance of this sector. The vital role played by management accounting practices for firms has been highlighted by many, including AbRahman et al. (2016), Cadez and Guilding (2012), Lachmann et al. (2013), Macinati and AnessiPessina (2014), Turner et al. (2017) and Uyar and Kuzey (2016). As indicated in Horngren (2009) and Uyar and Kuzey (2016), Management Accounting Practices (MAPs) are control tools that are utilized in the enhancement of the subunit and the general performance with the use of financial control, planning, and controlling of operations, whereby the resources of the firm are employed economically, and also through value creation.

SMEs in the manufacturing sector need to utilize MAPs to allow them to provide authentic information in a timely manner. This, according to Azudin and Mansor (2018) can ease managerial planning, evaluation, and control in firms to achieve better operational efficiency and optimal performance. In modern manufacturing particularly, lack of applicability of management accounting to managerial needs has been noted. Also, there 
appears to be a gap existing between management accounting theories especially with regard to actual management accounting. Furthermore, without comprehensive scrutiny of the real practice, Ittner and Larcker (2002) highlighted the challenge in envisaging the research transformation potential in applied disciplines including management accounting. Consistent empirical works are also necessary to allow the monitoring of developments and comparison of the current results with past ones (Brierley et al., 2001).

The use of MAPs is generally to determine product cost information, plan and control, find problems, and extrapolate possible risks (Abdel-Kader \& Luther, 2006; Angelakis et al., 2010; Armitage et al., 2016; Chenhall \& Langfield-Smith, 1998; Pavlatos \& Kostakis, 2015; Shields et al., 1991; Uyar \& Kuzey, 2016), and therefore for firms, MAPs are highly crucial tools. Notably, scholars all over the world are showing an increased interest in MAPs.

Within the context of developed nations, MAPs studies have been primarily concentrating on the practices of budgeting and costing, performance measurement, and a decision support system, and a number of studies (e.g., Abdel-Kader \& Luther, 2006; Angelakis et al., 2010; Armitage et al., 2016; Nuhu et al., 2017; Pavlatos \& Kostakis, 2015; Pavlatos \& Paggios, 2008) have reported such. Meanwhile, the application of MAPs in developing countries has been deliberated in some studies (e.g., Ahmad \& Leftesi, 2014; Ahmad, 2013; Ghasemi et al., 2015; Joshi, 2001; Joshi et al., 2011) and their significance in the success of organizations has been proven. In MAPs usage, however, there has been a disparity, particularly between developed and developing countries.

In developing countries, however, MAPs are not yet fully established, and among organizations in some of these countries, the use of MAPs has been less than efficient. Azudin and Mansor (2018) relevantly stated that this phenomenon may be caused by the fact that MAPs are not mandatory. In Jordan for instance, the use of MAPs in manufacturing SMEs has not been sufficient, and for this reason, this study will increase the understanding on MAPs usage among Jordanian manufacturing SMEs, adding to the literature and practice. 
The present study provides significant empirical substantiation concerning the degree of usage of MAPs among manufacturing SMEs in Jordan. Furthermore, for managers and decision-makers in SMEs, the present study presents the real role and the countless values of MAPs. Equally, other countries with comparable political, cultural, environmental, and economic circumstances as Jordan, the Middle East and the North African region especially, can benefit from this study as well.

\section{LITERATURE REVIEW}

MAPs provide organizations with the tools and techniques that can be employed to obtain the information that facilitates the attainment of effective and efficient usage and management of resources, which, according to Langfield-Smith et al. (2017), could add value to both customers and shareholders. MAPs generally take two forms namely, traditional MAPs and contemporary MAPs. Among the traditional MAPs are cost-benefit analysis, standard costing, return on investment, and variance analysis, alongside financial and internal oriented MAPs; short-term-focused MAPs and MAPs that include apportionments of arbitrary costs (Chenhall \& Langfield-Smith, 1998; Pavlatos \& Paggios, 2008).

There have been issues with the traditional MAPs and among them are their narrowness and inability in satisfying the information requirements, thus not being able to cope with rapid changes and challenges of the business environment of today. As a solution, contemporary MAPs have been introduced (Kaplan \& Johnson, 1987; Wu et al., 2007) specifically for achieving competitiveness, quality, speed, cost management, and customer satisfaction (Abdel-Maksoud et al., 2012). These MAPs are also able to correspond with today's dynamic business setting (Chenhall \& LangfieldSmith, 1999). Activity-Based Costing (ABC), Balanced Scorecard (BSC), and Activity-Based Management (ABM) are among the contemporary MAPs.

Chenhall and Langfield-Smith (1999) stated that contemporary MAPs are strategic, able to link the operations with the strategies and objectives of the organization, with integrated financial and non-financial information. Therefore, Jarrar and Smith (2014) considered MAPs as appropriate tools 
for strategic management. According to Langfield-Smith et al. (2017) organizations can use contemporary MAPs in their construction and implementation of strategies. Equally, entrepreneurial strategies can be pursued through contemporary MAPs (Jarrar \& Smith, 2014).

Despite the benefit of contemporary MAPs, traditional MAPs remain the popular choice among today's organizations due to easiness and low execution cost (Pierce \& O'Dea, 1998; Joshi, 2011; Ahmad, 2017). As found, the more modern techniques are being used as well but mainly to supplement the traditional ones, rather than replacing them.

Studies on MAPs in developed countries have been focusing on budgeting, costing, measurement and evaluation of performance, and a decision support system (see: Abdel-Kader \& Luther, 2006; Chenhall \& Langfield-Smith, 1998; Gehrke \& Horvath, 2001; Giannetti et al., 2002; Guilding et al., 2000; Hyvönen, 2005; Macinati \& Anessi-Pessina, 2014; Pavlatos \& Kostakis, 2015; Pierce \& O'Dea, 1998; Turner et al., 2017; Wijewardena \& De Zoysa, 1999). A comparative MAPs study among Japanese and Australian large manufacturing firms was carried out by Wijewardena and De Zoysa (1999) and the authors reported some notable differences between these countries.

Guilding et al. (2000) pertinently explored the strategic management accounting (SMA) tools used in the US, UK, and New Zealand, and concluded there was meagre use of most SMA tools, except for the competitor accounting and strategic pricing. In a related study on management accounting systems in Italy, Giannetti et al. (2002) found that for large and medium-sized industrial companies, measures of non-financial performance were usually used together with those of financial performance.

Comparatively examining the participation rates of several companies in European countries, Gehrke and Horvath (2001) found that companies in the United Kingdom showed $83 \%$ participation rates, those in Italy showed $72 \%$, those in France showed 41\%, while those Germany showed 98\%; all of these companies had familiarity with BSC. Additionally, Hyvönen (2005) in Finland discussed MAPs adoption on the level of adoption, its purported benefits, in addition to the established purposes for forthcoming developments associated with such practices. The author indicated that 
financial measures such as product profitability analysis and budgeting for controlling costs will remain important in future. Non-financial practices such as customer satisfaction and employee attitude will also be vital in future.

Abdel-Kader and Luther (2006) in the UK surveyed MAPs usage in the food and drinks industry and reported a consistent utilization of traditional management accounting. The authors also found increased use of information on quality cost, non-financial measures vital for employees, and rivals' strengths and weaknesses analysis. Additionally, more than half $(57 \%)$ of the 112 respondent companies utilized target costing at different levels. The authors accordingly noted a gap between the practices mentioned both in theory and practice.

In developing countries, management accounting scholars have examined many forms of MAPs (e.g., costing, budgeting, performance measurement and evaluation, and decision support systems). Among these studies include AbRahman et al. (2016), Ahmad and Leftesi (2014), Ahmad (2013), El-Ebaishi et al. (2003), Frezatti (2007), Ghasemi et al. (2015), Joshi (2001), Sulaiman et al. (2004), Uyar and Kuzey (2016), Waweru et al. (2004), and Wu et al. (2007). There is still a wide utilization of the traditional management accounting techniques which may be factored by the unfamiliarity towards the contemporary techniques, lack of expertise, as well as lack of top management support. Again, the traditional practices were identified as more commonly used by companies in these regions.

What can therefore be deduced is that MAPs among SMEs appear to be restricted and as shown, MAPs are generally associated with advanced nations. Furthermore, it was mentioned in Mitchell and Reid (2000) that works on management accounting, particularly on technical innovation and development, have been concentrated in bigger firms. Meanwhile, there has been very little work focusing on smaller firms concerning the expertise and competency in innovation in management accounting. MAPs among SMEs are therefore worth the scrutiny. 


\section{INNOVATION DIFFUSION THEORY}

In trying to understand MAPs, researchers of management accounting have used a variety of explanatory frameworks recently. The Innovation Diffusion Theory, which is seen as very promising for understanding the diffusion of innovation in emerging environments (see, Tolbert \& Zucker, 1983; Abrahamson, 1991; Scapens, 1994; Scott, 1995; Haunschild \& Miner, 1997; Chua \& Petty, 1999; Hage, 1999; Davis \& Marquis, 2005). Bjørnenak (1997), describes diffusion as the process of spreading or disseminating innovation. Further, an idea or practice that is regarded as new by the adoption unit is considered as innovation (Zaltman et al., 1973; Hage, 1980; Damanpour, 1991; Zammuto \& O’Connor, 1992).

Attempts to investigate the factors impacting the diffusion of innovation have been made by researchers. In doing so, they tried to find the attributes of innovation and figure out why certain innovations are extensively adopted as opposed to others. There have also been many efforts among researchers to classify the factors known to impact the diffusion of innovation by way of the literature. This can be seen in the works of Rogers (1995) and Askarany and Smith (2003). In Rogers (1995) for example, these factors are classed into: attributes of innovations, the type of innovation-decision, the nature of communication channels, the nature of social systems, and the extent of change agents' promotion efforts. Using the work of Rogers (1995) as the base, a model was constructed by Askarany and Smith (2003). This model classified the factors that impact the diffusion of innovation as follows: attributes of innovation, attributes of adopters and attributes of social systems which comprise those influential factors that cannot be linked with the other two groups of factors.

The work of Askarany and Smith (2003) is also in line with the view of Rogers (1995), which states the characteristics of innovation as the most crucial influencing factors on innovation diffusion. Several factors known to impact innovation processes in organizations have also been highlighted by researchers. Among these factors are strategy, structure, and financial resources. Further, factors associated with organizational policies were reported by Van de Ven and Poole (1990). These include decision making influence and dependency on outside groups. 
Further, as presumed by the pro-innovation standpoint, innovations will bring benefit to organizations that adopt them and adopters that are rational make technically efficient choices autonomously (Rogers, 1995). Based on this standpoint, if innovations are beneficial to the adopter, they will be disseminated, but when innovations are not beneficial to the adopter, they will be rejected. Comparatively, innovations that are deemed inefficient will never be adopted while those deemed efficient will not face rejection. Here, innovation and adoption are generally regarded as a good thing, while fresh ideas not regarded as valuable are likely to be termed as mistakes instead of innovation, whereas the decision not to adopt is regarded as negative and termed as resistance to innovate (Van de Ven, 1986). The pro-innovation would be of value when innovation adoption is judiciously clarified and where the benefits attained from the adoption are discernible (Newell et al., 2001). However, in the real organizational contexts, this will be tough to achieve particularly when dealing with the adoption of administrative innovation, like management accounting techniques.

Somehow, this viewpoint does not explain the diffusion of inefficient innovations or the rejection of the efficient ones (Abrahamson, 1991, 1996; Rogers, 1995). As claimed by Rogers (1995), the bias of pro-innovation causes the neglect of very crucial aspects of diffusion and thus, wider contexts of innovation diffusion should be examined by researchers to deal with this bias. Rogers also stressed the importance of increasing the comprehension of the motivation for adopting an innovation.

Thus, to survive, organizations do not just need to achieve production efficiency; they also need to adopt the practices and procedures that are acceptable in their institutional environment, and they do that to ensure their continuance and survival (DiMaggio \& Powell, 1983). In this relation, the innovation diffusion theory offers an organizing framework that can be employed to identify the main obstacles impeding the innovation or motivates it and to evaluate their relative significance. It also offers the opportunity of expanding our understanding of the management accounting phenomenon (Atkinson et al., 1997). 


\section{RESEARCH METHODOLOGY}

Mixed-methods are used for offsetting the weaknesses associated with the use of just one approach. Teddlie and Tashakkori (2009) indicated that the utilization of mixed methods enables the generalization of data from the quantitative approach and the formation of 'thick and rich' data with the use of qualitative methods. Questionnaires and interviews were used in this study to find out the application of management accounting practices among SMEs in Jordan, according to the viewpoints of heads of accounting departmentslfinancial managers. As reported in JCI (2015), there were roughly 1139 registered manufacturing companies in the local chambers of the industry in Jordan, and within this number, 98\% were SMEs. These companies were appropriate as the study sample and they were chosen using the probability sampling technique, which, as Sekaran and Bougie (2016) stated, provides all respondents similar chances to be selected.

In phase one, 291 sets of questionnaires were dispersed to different types of selected manufacturing SMEs and a total of 159 usable questionnaires were obtained. There were two main sections in the questionnaire and the details are as follows: Section One contained items on the aspects of the demography of the company, while the following Section Two contained 37 items that explore MAPs using the four following dimensions: costing practices, budgeting practices, performance measurement system, and the decision support system. The measures used in this study were based on past studies including Abdel-Kader and Luther (2006), Ahmad (2013) and Chenhall and Langfield-Smith (1998).

In Phase Two of data gathering, in-depth, semi-structured interviews were employed. Gill et al. (2008) are among the researchers who opined that interviews are the best method of data gathering in qualitative research. Creswell (2013) further added that interviews assist the researcher in interacting with the participants being interviewed. 10 respondents in Phase Two was selected from participants in Phase One. Nonetheless, owing to tasks related to their position or personal causes, only six (6) respondents were interviewed. They were chosen due to their prominent role in the company and the capacity to provide accurate responses to the interview questions. The position held by them are either as financial managers or heads of accounting departments in manufacturing SMEs in Jordan. 


\section{SURVEY RESULTS AND DISCUSSION}

\section{Background Information of Responding Companies}

The survey phase involved the provision of company information by the respondents. Among the information provided included company age, manufacturing activities, number of employees, annual sales, and ownership type. Table 1 presents the details.

Table 1: Background Information of Responding Companies

\begin{tabular}{|c|c|c|c|}
\hline Years of Operation & Frequency & Percentage & Cumulative Percentage \\
\hline $6-10$ years & 19 & 12 & 0 \\
\hline $11-15$ years & 38 & 24 & 12 \\
\hline More than 15 years & 102 & 64 & 36 \\
\hline Total & 159 & 100 & 100 \\
\hline Manufacturing Activities & Frequency & Percentage & Cumulative Percentage \\
\hline Food and beverages & 38 & 24 & 0 \\
\hline Electronic & 19 & 12 & 24 \\
\hline Leathers and clothing & 24 & 15 & 36 \\
\hline Pharmaceutical and medical & 19 & 12 & 51 \\
\hline Chemical & 54 & 34 & 63 \\
\hline Other & 5 & 3 & 97 \\
\hline Total & 159 & 100 & 100 \\
\hline Number of Employees & Frequency & Percentage & Cumulative Percentage \\
\hline $10-49$ & 43 & 27 & 0 \\
\hline 50- 249 & 116 & 73 & 27 \\
\hline Total & 159 & 100 & 100 \\
\hline $\begin{array}{l}\text { Annual Sales Turnover (in } \\
\text { Jordan Dinars) }\end{array}$ & Frequency & Percentage & Cumulative Percentage \\
\hline 1- 3 million JD & 49 & 30.8 & 0 \\
\hline More than 3 million JD & 110 & 69.2 & 30.8 \\
\hline Total & 159 & 100 & 100 \\
\hline Type of Ownership & Frequency & Percentage & Cumulative Percentage \\
\hline Government-owned company & 10 & 6.3 & 0 \\
\hline Private company & 114 & 71.7 & 6.3 \\
\hline $\begin{array}{l}\text { Shared between private sector } \\
\text { and foreign partner }\end{array}$ & 22 & 13.8 & 78 \\
\hline $\begin{array}{l}\text { Shared between government } \\
\text { and private sector }\end{array}$ & 13 & 8.2 & 91.8 \\
\hline Total & 159 & 100 & 100 \\
\hline
\end{tabular}

Note: Jordanian Dinar (JD) = 1.41 US Dollar $(\$)$ 
As can be observed in Table 1, the majority of companies (64\%) had been in operation for more than 15 years, while $24 \%$ of them had been in operation for between 11 and 15 years, whereas only a small fraction (12\%) were in operation for between 6 and 10 years. Based on the information provided in the Table, it can be said that the companies were generally experienced in their operation domain. In regards companies' manufacturing activities, 34\% were involved in chemical products, while $24 \%$ were focussed on food and beverages. Meanwhile, leathers and clothing were the domain of $15 \%$ of the companies, electronics, $12 \%$ pharmaceuticals and medicine, $12 \%$ and a small fraction $-3 \%$ were involved in other fields.

The majority of the companies ( $73 \%$ ) had 50 to 249 employees, while over one fourth $(27 \%)$ of the companies hired between 10 and 49 employees. In terms of annual sales turnover, more than half (69.2\%) of the companies generated more than 3 million JD, while $30.8 \%$ of the companies had generated 1-3 million JD. These results show that medium-sized companies had a higher response rate when compared to their small counterparts. Further, the study found that the majority of the studied companies $(71.7 \%)$ were private companies, whereas a small fraction $(6.3 \%)$ were governmentowned companies. Meanwhile, join venture companies were of two types, with $13.8 \%$ being joint ventures between the private sector and a foreign partner, and $8.2 \%$ being joint ventures between a government company and a private partner.

\section{Usage Rate of Management Accounting Practices}

Table 2 shows that all the listed MAPs were used by the manufacturing SMEs with the exclusion of activity-based costing (ABC), absentee rates measures, and employee turnover measures at $8.1 \%$ of MAPs. Meanwhile, 11 MAPs practices (29.7\% of MAPs) were found to be highly used by at least $70 \%$ of the companies, while 10 practices ( $27 \%$ of MAPs) were used moderately by at least $35 \%$ of the companies, whereas 13 (35.2\% of MAPs) had low usage rates of less than $35 \%$ of the companies. 
Table 2: Descriptive Statistics for Usage Rates of MAPs

\begin{tabular}{|c|c|c|c|c|}
\hline $\begin{array}{l}\text { Management Accounting } \\
\text { Practices } \\
\end{array}$ & $\begin{array}{l}\text { Usage Rate } \\
\text { percentage } \%\end{array}$ & Mean & $\begin{array}{l}\text { Standard } \\
\text { Deviation }\end{array}$ & Rank \\
\hline \multicolumn{5}{|l|}{ High Usage } \\
\hline Process costing & 100 & 4.22 & .42 & 1 \\
\hline Budget frequency $\backslash$ Annually & 99.4 & 4.49 & .51 & 2 \\
\hline Sales growth & 93 & 4.29 & .688 & 3 \\
\hline Financial position budget & 84.3 & 4.34 & 1.34 & 4 \\
\hline Job costing & 84.3 & 4.14 & .83 & 5 \\
\hline Operating income & 83 & 4.21 & .712 & 6 \\
\hline Cash flows & 81.8 & 4.26 & .813 & 7 \\
\hline Product profitability analysis & 81.1 & 4.23 & .941 & 8 \\
\hline Variable costing & 79.9 & 3.84 & .46 & 9 \\
\hline Cash flow budget & 76.7 & 4.10 & 1.24 & 10 \\
\hline Production budget & 74.8 & 4.31 & .92 & 11 \\
\hline \multicolumn{5}{|l|}{ Moderate Usage } \\
\hline Absorption costing & 68.5 & 3.60 & .67 & 1 \\
\hline Break-even analysis & 61.6 & 3.58 & 1.149 & 2 \\
\hline Payback & 59.8 & 3.43 & 1.250 & 3 \\
\hline Capital budgeting & 53.5 & 3.16 & 1.85 & 4 \\
\hline Target costing & 53.4 & 3.57 & .56 & 5 \\
\hline Net present value & 47.8 & 3.16 & .974 & 6 \\
\hline On-time delivery & 45.3 & 3.82 & .945 & 7 \\
\hline Defect rate & 44.7 & 3.70 & .848 & 8 \\
\hline Zero-based budgeting & 40.3 & 2.90 & 1.60 & 9 \\
\hline Standard costing & 37.1 & 3.37 & .48 & 10 \\
\hline \multicolumn{5}{|l|}{ Low Usage } \\
\hline Budget frequency $\backslash$ Monthly & 34 & 2.80 & 1.72 & 1 \\
\hline Internal rate of return & 31.5 & 3.19 & .995 & 2 \\
\hline Number of warranty claims & 29.6 & 2.79 & 1.044 & 3 \\
\hline Return on investment & 22 & 3.35 & .746 & 4 \\
\hline Batch costing & 21.4 & 3.09 & .83 & 5 \\
\hline Variance analysis & 19.5 & 3.18 & .967 & 6 \\
\hline Stock control model & 15 & 2.76 & .845 & 7 \\
\hline Flexible budget & 11.3 & 3.04 & .70 & 8 \\
\hline Survey of customer satisfaction & 10 & 2.91 & .924 & 9 \\
\hline Accounting rate of return & 6.3 & 3.10 & .409 & 10 \\
\hline Manufacturing lead time/cycle time & 6.3 & 2.53 & 1.066 & 11 \\
\hline Contract costing & 5 & 2.89 & .64 & 12 \\
\hline Number of customer complaints & 1 & 3.00 & .225 & 13 \\
\hline \multicolumn{5}{|l|}{ Never Use } \\
\hline Employee turnover & 0.0 & 1.21 & .578 & 1 \\
\hline Absentee rates & 0.0 & 1.12 & .495 & 2 \\
\hline Activity based costing (ABC) & 0.0 & 1.11 & .37 & 3 \\
\hline
\end{tabular}

Note: Usage rate equation= number of practices divided on total MAPs (37). (High usage, $70 \%$ and above): $11 \backslash 37=29.7 \%$, (moderate usage, $35 \%$ to $70 \%$ ): $10 \backslash 37=27 \%$, (low usage, less than $35 \%$ ): $13 \backslash 37=35.2 \%$, (never use $0 \%$ ): $3 \backslash 37=8.1 \%$. 
Overall, the results show that the usage rate of MAPs among manufacturing SMEs in Jordan is somewhat low when compared to SMEs in other countries. For instance, Joshi (2001) reported that in India, an adoption rate of $70 \%$ or lower would be classed as a low adoption rate, and 14 MAPs were employed by at least $80 \%$ of the examined companies. Meanwhile, in Finland, Hyvönen (2005) found that at least $90 \%$ of the companies employed 20 MAPs, and in this country the adoption rate of $82 \%$ or less would be considered as low. In addition, studying MAPs in Australia, Chenhall and Langfield-Smith (1998) found that adoption of $80 \%$ or less would be considered a low adoption rate. Further, the authors reported that 15 MAPs were implemented by $90 \%$ of the companies at least, while the other 16 practices were applied by at least $80 \%$ of the companies.

Among Jordanian manufacturing SMEs, MAPs usage rate appears to be comparable to that of Malaysia (see Ahmad, 2013) and Iran (see Ghasemi et al., 2015). Also, in Jordan, MAPs usage rates among manufacturing SMEs appear to be higher than those reported in Arab countries including Libya (Ahmad \& Leftesi, 2014). As can be observed in Table 2, in Jordanian manufacturing SMEs, high-level MAPs usage comprises the following: process costing (100\%), annual budgeting systems $(99.4 \%)$, sales growth (93\%), financial position budget and job costing (84.3\%), operating income $(83 \%)$, cash flows $(81.8 \%)$, analysis of product profitability $(81.1 \%)$, variable costing (79.9\%), cash flow budget (76.7\%), and production budget $(74.8 \%)$.

Meanwhile, the popularity of MAPs as found in this study is comparable to the findings of Ahmad and Leftesi (2014), Ahmad (2013), Chenhall and Langfield-Smith (1998), Hyvönen (2005), and Joshi (2001), but in general, the usage rates found in these studies were generally higher than those reported for Jordan. As an example, the use rate of product profitability analysis in the present study was at $81.1 \%$. In comparison, Chenhall and Langfield-Smith (1998) in Australia reported 89\% of usage rate for the exact practice. Also, there was a moderate implementation of net present value practice for the practices of the decision support system, and in the context of Iran (Ghasemi et al., 2015) and Libya (Ahmad \& Leftesi, 2014). Meanwhile, in Malaysia (see Ahmad, 2013), Libya (see Ahmad \& Leftesi, 2014) and Iran (Ghasemi et al., 2015), and equally in this study, ABC and non-financial measures were found to be the less implemented MAPs. 
Overall, the findings show that the use of advanced MAPs has not been popular among the examined companies in this study and the situation has also been reported in past related studies. Guilding et al. (2000) who examined diverse countries on the subject of advanced MAPs accordingly found low usage rates. Furthermore, several past studies (e.g., Ahmad \& Leftesi, 2014; Bergamin Barbato et al., 1996; Saez-Torrecilla et al., 1996; Szychta, 2002) indicated ignorance towards such techniques among the examined companies. Thus, it can be said that there have been a comparatively low usage rate of MAPs among manufacturing SMEs in Jordan as opposed to their counterparts in developed countries.

\section{INTERVIEW RESULTS AND DISCUSSION}

This section comprises the outcomes of semi-structured interviews with six Jordanian manufacturing SMEs. As previously mentioned, the sample was dictated by the willingness of companies to participate in the interview. Table 3 shows each interview in detail.

Table 3: Details of the Interview

\begin{tabular}{|c|c|c|c|}
\hline Company & Interviewee Position & Manufacturing Activity & DurationIMinute \\
\hline A & Financial manager & Chemical manufacturing & 55 \\
\hline B & $\begin{array}{l}\text { Head of accounting } \\
\text { department }\end{array}$ & $\begin{array}{l}\text { Manufacturing of food and } \\
\text { beverages }\end{array}$ & 50 \\
\hline C & $\begin{array}{l}\text { Head of accounting } \\
\text { department }\end{array}$ & Aluminium manufacturing & 55 \\
\hline D & Financial manager & $\begin{array}{l}\text { Manufacturing of plastics and } \\
\text { melamine }\end{array}$ & 45 \\
\hline E & $\begin{array}{l}\text { Head of accounting } \\
\text { department }\end{array}$ & Tire manufacturing & 50 \\
\hline $\mathrm{F}$ & $\begin{array}{l}\text { Head of accounting } \\
\text { department }\end{array}$ & $\begin{array}{l}\text { Manufacturing of } \\
\text { pharmaceutical and medical }\end{array}$ & 45 \\
\hline
\end{tabular}

The purpose of the interview was to discover the consequences associated with the topic that were not previously covered in the survey phase. In this regard, interviews were used to answer the study's research objective: "The motivation of using MAPs and main obstacles impeding using MAPs." Also, this study explored the role of MAPs in Jordanian manufacturing SMEs. These findings generated new ideas for future studies. 
The analysis was performed on the interview transcripts using thematic analysis as described by Boyatzis (1998) and Braun and Clarke (2006). As previously mentioned, thematic analysis comprises a process that involves the encoding of qualitative information. This type of analysis refers to a method that consists of identification, analysis, and reporting patterns (themes) inside the data (Braun \& Clarke, 2006). For the analysis of qualitative data, thematic analysis is a research tool that is both flexible and useful because theoretically, it can generate data that are both rich and detailed (Braun \& Clarke, 2006). When applying this method, Boyatzis (1998) and Braun and Clarke (2006) mentioned that the creation of themes from the data can be done either inductively or deductively.

This study employed a deductive analysis because the process of data coding is in accordance with the specific research objective being addressed. Notably, the theory discussed guides the data coding method. The themes for MAPs roles and MAPs use in SMEs generated during coding were underpinned by the Innovation Diffusion Theory. Additionally, themes that were not visible from the data were created through interpretation and understanding (Boyatzis, 1998; Braun \& Clarke, 2006). The interview data were transcribed and reread for familiarization. As suggested by Boyatzis (1998) and Braun and Clarke (2006), the researcher needs to understand and become immersed in the data at the early stage of data analysis. As a result, the initial coding patterns were identified. This facilitated coding in the next stage.

This study used the theory-driven approach to develop themes, thus, the coding process started with specific questions in mind. First, initial themes were generated based on the Innovation Diffusion Theory. For example, under the theory, initial themes are the role of MAPs and reasons for usage. To facilitate the coding process, NVivo11 was used to create nodes based on these initial themes. Then, the researchers coded the data based on these nodes. Codes, nodes, and themes were systematically reviewed and refined to ensure that they reflected the subject matter of this study.

\section{The Role of Management Accounting Practices in SMEs}

The data obtained from the interviews affirmed the use of MAPs among respondent companies for diverse purposes. In particular, fixed 
cost, the variable cost, standard cost, and target cost systems have been utilized by these companies in forming pertinent information for strategic purposes, which involves costs reduction and product pricing for fulfilling the market competition. Further, costing tools have also been used by the respondent companies in their determination of accurate product cost information. Costing tools have also been used by the respondent companies in their effort to prevent distortion on the product cost information as it may impact selling prices, budget preparation, and decision-making. This study found a consistency between the viewpoints of the interviewees and the conclusion made in Chenhall (2005) and Kaplan and Cooper (1998) on the use of cost practices in the formation of applicable information for strategic purposes which involves product planning (e.g., product pricing), and also for managerial purposes (e.g., cost reduction). The following views are confirmations:

"We are using fixed cost, the variable cost, standard cost systems, and target cost, for determining the accurate product cost information and avoiding the production of distorted product cost information for determining the selling prices" (Company A).

"Our company uses standard costs and target cost to reduce the costs. This is because the competition in the market causes the inability to increase our product prices" (Company B).

"We are using the variable costs, target costs and standard costs to serve the company strategy such as pricing the products and budget preparation" (Company C).

Budget practices are regarded as crucial to the respondent companies considering that budgets are regarded as financial plans which furnish the information for planning, controlling, and problem discoveries. The interviewees also highlighted the vital role of budgets in their financial planning and their control of expenses and costs. This is in line with Chenhall and Langfield-Smith (1998), Joshi (2001) and Tsamenyi et al. (2004), who reported planning and control as vital purposes of budget systems. Similarly, Uyar and Kuzey (2016) mentioned that MAPs are generally for the improvement of the subunit and overall unit performance achieved via operation planning, operation control, financial control, economic usage of business resources, and value creation. The following views are proofs: 
"Primarily for financial planning and operation, and controlling costs and expenses, we are using sales and production budgets" (Company A).

"By relying on budgeting system for planning and control of the costs, we can discover problems and try to solve them" (Company B).

"We believe the budget system is one of the success tools, through translating the plans and using the financial resources for a future period yearly to perform the functions of planning, control and motivation within our company" (Company C).

He added:

"In fact, the budgets prepared for planning should be realistic, whereas budgets used for motivating purpose are required to be based on possible outcomes" (Company C).

It can therefore be construed that various financial measurements were being utilized by Jordanian manufacturing SMEs providing that the obtained outcomes over some period were as projected or were contradictory. The measurements were also utilized in the prediction of potential risks. The utilization of indicators of financial performance with quarterly budgets was also reported by the respondent companies. This was to assure satisfactory company performance. In addition, performance measurement has been a commonly used tool in the evaluation of employee efforts and customization of management bonuses. Chenhall and Langfield-Smith (1998) and Hyvönen (2005) are among those who are in agreement with the findings of this study on the tools of performance measurement tools. The following views are attestations:

"These practices are like tissues that are linked to one another. For example, we apply performance measurement systems, both financial and non-financial, to become a control and measure system, for instance, we are evaluating sales growth, earnings, cash flow and level of customer satisfaction. Also through the analysis tools, we can forecast risks surrounding our company", (Company A). 
"We are linking the financial performance indicators with the quarterly budgets to ensure that our company performance is going in the right way" (Company B).

He added:

"In other words, measurement tools help us to determine that the results of the period are as expected or contrary to expectations" (Company B).

"Through measurement tools, we measure the returns and growth of revenue, which is itself a control system that serves the interests of our company" (Company C).

He added:

"We evaluate the efforts of employees and customize the management bonuses based on performance indicators" (Company $C$ ).

The utilization of decision support tools has been affirmed by the interviewees, and as found, these tools were used for a multitude of purposes. As shown, financial returns and product profitability analysis were utilized by the respondent companies in the formation of applicable information for expansion, issuance of new products, price amendments, and the approximation of prospective risks. Furthermore, in eradicating the financially unfeasible products, product profitability analysis has been used by manufacturing SMEs.

According to the interviewees, return on investment and payback period were crucial for the company because both provide the company with the needed information when evaluating the new projects and potential investments. With the utilization of the output from profitability analysis, the interviewees were able to make appropriate decisions for the organizations, particularly through risk management associated with products and pricing and similar situations that were reported in Abdel-Kader and Luther (2006), as well. The following views are verifications: 
"In fact, through relying on using the output of financial returns and product profitability analysis, we make decisions on expansion process, issue new products, modify the price and estimate the potential risks" (Company A).

He added:

"Of course we analyze the profitability of each product separately because of the variety of our products" (Company A).

"We are relying mostly on product profitability analysis to get rid of the products that are not financially feasible" (Company B).

He added:

"For evaluating the new projects and investments expansions, we are using the return on investment and payback period because of its simplicity and ease of use" (Company B).

"We seek to manage risks related to our industry in a complex sector and high-level competitiveness that surrounds Jordan by using the output of return on investment and profitability analysis risks from products failures at any phase in production, development, and pricing" (Company C).

As affirmed by the interviewees, their companies still benefit from the tools of traditional management accounting. The utilization of traditional budgets for financial planning, performance control, and performance assessment with the application of timetables was also affirmed by the interviewees. Furthermore, direct cost tools were also used in the determination of product cost information. With the use of financial measurements, yearly calculations of financial returns were carried out by the respondent companies.

Inadequacies in traditional management accounting tools were equally highlighted by the interviewees. According to them, there have been challenges in the adjustments of product costs, and the comprehension of price fluctuations and consumer behaviour. The traditional management accounting tools have been criticized, but they still contributed greatly to manufacturing SMEs in Jordan. The comments below are insightful: 
"We are using budgets as an instrument of planning, control, and assessment of the performance, through the development of timetables to perform specific programs and plans" (Company D).

He added:

"Yes as I mentioned to you, we believe the budgets system is one of the success tools, through planning on using the financial resources for a future period yearly" (Company D).

He added:

"But we are facing some difficulties... In regards to market behaviour, we are unable to understand what is happening from fluctuations in prices. In addition, we are unable to understand consumers' behaviour, of course, we tried and are still trying to predict what is happening based on the outputs of our systems, but we believe that the results are not precise yet" (Company D).

"In fact, we are using direct costs and budgets system for the planning process and controlling costs. Also, we calculate our yearly financial returns we believe it is sufficient to service our company strategy to some extent ....but we have difficulties in adjusting the cost of the product" (Company E).

"In general we are using the traditional budgets and cost accounting system. Also, we calculate the financial returns. Furthermore, we are covering the required information about the competitors through marketing staff gave the limited financial resources of the company" (Company F).

Rogers (2010) presented the view of pro-innovation by stating that innovations will produce benefits to the user organizations. This means that innovations that bring benefits to the adopter will be likely to diffuse. In the context of manufacturing SMEs in Jordan, MAPs increased benefits. This is in agreement with Rogers. 


\section{The Motivation of Using Management Accounting Practices in SMEs}

In the research subject, interviewees perceived that the use of MAPs is related to numerous things. In particular, when the environmental uncertainty level is high (which results from dynamism and hostility), organizations are inclined to adopt a large amount of financial and non-financial information. Also, they opined that MAPs play a critical role in allowing companies to survive in highly competitive environments.

The interview results suggest that organizational and external reasons have a significant role in the diffusion of MAPs. Such views are in line with the Contingency Theory (see, Otley, 1980; Chenhall, 2003). Notably, the opinions of the interviewees were similar to the views reported in the management accounting literature. For instance, Chapman (1997), Hoque (2005), Abdel-Kader and Luther (2008) and Cadez and Guilding (2008), indicated the important role that accounting plays in facing uncertainty. Additionally, when the environmental uncertainty level is high, organizations are inclined to adopt a vast amount of financial and nonfinancial information (Gordon \& Miller, 1976). The following statements are evidence of these views:

"The globalization of consumer markets and producers that led to a state of uncertainty; all this requires modern systems that serve the goals of the company and keep it alive in an environment of uncertainty" (Company A).

"Changing environment needs information that is instant and timely. Thus, a company has to prepare periodic reports annually, half-yearly, quarterly, or even monthly" (Company B).

"A company that operates in a volatile environment needs to have an accounting system that is ready to offer any information to evaluate the company's internal and external conditions" (Company C). 
He added:

"Handling the dynamic environment requires many detailed and accurate information, which should be made available at the appropriate time and assist us in risk management" (Company C).

Moreover, interviewees indicated that a competitive environment is one of the reasons that forced companies to use MAPs. They also opined that MAPs play a critical role in companies that survive in a highly competitive environment. Such views are supported by Mohamad et al. (2015). These authors are also of the opinion that product prices are counted as a basic competition while price reduction is typically linked with cost reduction. Therefore, for companies operating in a competitive environment, computation and controlling costs is a priority. This is illustrated by the following comments:

"To say that competitiveness affects the cost accounting tools more than the budget practices or vice versa is impossible as these practices are like tissues; they are related to each other. For instance, the precision in the budget preparation needs precise cost information so that it can be a successful instrument to fairly measure and make a decision" (Company B).

He added:

"It is a fact that price comes first and quality comes second when it comes to the most important elements of competition. No company can decrease their prices more than its competitors especially in the situation where the costs incurred by the company are greater than the costs borne by the competitors. The price reduction is typically linked with costs reduction, so the price reduction process will not be random. Thus, the cost system has to have the ability to make available detailed information on cost structures; for instance, what are the fixed costs and variable costs? The dispensable costs, the indispensable cost, and then, what are the sunken cost [sic] and so on? So, I think that the costs tools are highly impacted by competition" (Company B). 
"Operating in the highly competitive environment requires diversity in the use of multiple performance measure practices; particularly the non-financial measures, but we also cannot neglect the importance of other tools" (Company C).

He added:

"The competitive intensity in the market in all levels, internal and external, led us to change and modify the company's strategy and policies, which is difficult to achieve if we use the traditional system" (Company C).

In line with the view of Henderson and Venkatraman (1993), managerial practices are consistent with strategic organizational priorities. The interviewees confirmed that company strategy compels them to use specific techniques. This is because each type of business strategy needs broad and accurate accounting information to measure performance. As mentioned by respondents, MAPs applied in their companies offer accurate accounting information regardless of the type of strategy. Such views are supported by Shank (1996) and Cadez and Guilding (2012), who stated that MAPs offer benefits to organizational strategy. The managerial mentality for differentiation and low-cost strategies is not the same. This is expected to impact preferences for some MAPs. It was also apparent from the interviews that when a company is equipped with advanced technology and has a complicated production process, that more advanced and precise tools are used. This is illustrated by the following comments:

"Surely, our cost structure is complicated, because of the diversity of our products. I believe we need comprehensive and accurate accounting information regardless of the type of strategy" (Company A).

"Differentiation strategy is the present and future of our company, where we are focused on a particular type of customers in addition to focusing on the brand. Improving product quality and maintaining a good relationship with a layer of target customers require us to use more modern systems such as management accounting tools; thus, whatever method is used, it will need to combine different kinds of information" (Company B). 
He added:

"We are using advanced production technology in manufacturing processes, which requires a more advanced and accurate accounting tool" (Company B).

As presumed by the pro-innovation standpoint, innovations benefit the organizations that adopt them, and users that are rational make technically efficient choices autonomously (Rogers, 1995). Based on this viewpoint, if innovations are beneficial to the adopter, they will diffuse, but when innovations are not beneficial to the adopter, they will be rejected. Comparatively, innovations that are deemed inefficient will never be adopted while those deemed efficient will not face rejection. Shields (1995) and Krumwiede (1998) are among those who noted the creation of management accounting tools are a practical solution for problems linked with traditional systems in generating complete and accurate accounting information. Also, the shortcomings of existing cost systems have a major role in encouraging companies to use MAPs (Chung et al., 1997). In this study, interviewees affirmed that flaws in traditional systems were one of the motivators for MAPs usage. This is illustrated by the following comments:

"Actually, the traditional system is unable to meet the demands of increasing automation in company production. Also, the traditional system did not provide useful information for management to fulfil our future ambition" (Company A).

"The traditional system is no longer reliable, which led us to replace it with a more recent system. We tried to control costs while maintaining the same quality of the product but we found a difficult to achieve that through the traditional system. The system was unable to provide accurate cost" (Company B).

"Inaccuracy of control of the costs occurs during the company use of the traditional system, especially when we have an increase in the costs, including production costs, overhead costs and administrative costs" (Company C). 
Previous experiments on large companies benefited from MAPs use are another reason for MAPs adoption, according to interviewees. In this regard, organizations adopt modern practices such as MAPs because they are effective or because they are mimicking competitors. The following statements are evidence of these views:

"To improve the overall company performance, in line with the previous experiments for the large companies" (Company A).

"Management accounting practices are used by other Jordanian companies which are considered as a leader in the industry. Those companies have benefited from the use of the system" (Company B).

"Actually, there are many successful companies in Jordan that are similar to our industry that is already applied management accounting practices" (Company $C$ ).

\section{The Main Obstacles Impeding Using Management Accounting Practices in SMEs}

The interviewees perceived that the reasons for not using MAPs are related to numerous sources. One reason for not using MAPs is insufficient MAPs knowledge and awareness among top management staff. Similarly, poor accountant MAPs skills and experiences force the organizations to not adopt any new techniques. This is in line with the findings of Byrne (2011). The interviewees mentioned that possible reasons for insufficient knowledge may because the accounting education system in Jordan still relies on the traditional method of learning. The following statements are evidence of these views:

"The top management has to make countless decisions. There is also a lack of awareness in terms of the management accounting practices" (Company E).

"Actually, the majority of accountants, and I am one of them; we have no complete knowledge of all MAPs. I think the accounting education systems in our universities are the cause" (Company $D)$. 
He added:

"Our staff members do not have sufficient skills and experience to use management accounting practices" (Company D).

"In fact, the system in Jordan just started, most of the expert staffs need a high salary" (Company E).

Support from top management is a crucial factor that impacts the implementation of management accounting systems (Shields, 1995; Naranjo-Gil \& Hartmann, 2006; Intakhan, 2014). Top management support is a critical factor to MAPs adoption by providing time, software, training programs, and resources for the implementation of management accounting tools (Gunasekaran, 1999; Askarany \& Smith, 2004; Maelah \& Ibrahim, 2006; Intakhan, 2014). In this regard, the interview with company $F$ confirmed that there is a lack of management support for MAPs usage as well as negligent MAPs spending.

"The policies and priorities of our top management do not support such practices; there is a priority for spending on expansion and modernization of production technology" (Company F).

Using MAPs necessitates financial capacity. The interviewees mentioned a lack of financial resources as a reason for MAPs non-usage. In particular, the financial status of may make the company unable to implement MAPs. This is supported by Wang (2014), Kim et al. (2016), and Madrid-Guijarro et al. (2016), who pointed out that financial accessibility constraints are a significant factor negatively affecting innovation. According to Otley (1980) and Ittner et al. (2003), environmental and organizational factors influence the use of MAPs. This is illustrated by the following comments:

"We actually have a difficult financial situation, and thus, our attention is primarily on meeting the necessary obligations" (Company E).

"MAPs are not among our priorities. This is because we have no external financial resources" (Company D). 
"MAPs are not easy to use because MAPs require spending money. Right now, we cannot afford it" (Company F).

MAPs are costly systems. In this regard, interviewees affirmed the high cost associated with the implementation of MAPs. This result is consistent with Cohen et al. (2005), who reported high costs associated with system implementation and consulting companies as major difficulties in the use of ABC. In other words, MAPs specifications (i.e., its cost and complexity) are a MAPs characteristic and are a reason to not use MAPs. The following statements are evidence of these views:

"MAPs system is very costly to use. I mean, using it will force us to spend more money, and we may not even achieve new or best results" (Company D).

"MAPs are actually a costly system. It requires a huge budget. The issue here is; we are a medium-size company. This makes us unable to compare our company with large companies" (Company E).

"We are comfortable with the current system. We think it is better than MAPs system because MAPs systems are very costly and its implementation also needs an expensive consultant" (Company F).

Impediments to new MAPs use identified by interviewees is a lack of company need, thus emphasizing the role of the demand side perspective in MAPs diffusion. The opinions of interviewees were similar to some viewpoints reported in the management accounting literature. For instance, Yazdifar and Askarany (2009) and Duh et al. (2009) are among those who mentioned the existence of some companies that do not practice modern accounting systems due to their satisfaction with traditional systems. In relation to this finding, the head of the accounting department of company F remarked:

"We are satisfied with the system that we have now as opposed to having to afford the cost of the alternative system. The traditional system that we use is in line with our company strategy" (Company F). 
The inconsistency of advanced techniques compared to traditional techniques in terms of relative MAPs benefits causes difficulty in identifying benefits. These items are related to MAPs attributes. In this regard, interviewees confirmed the non-usage of MAPs owing to the disadvantages associated with the system itself and ambiguity about MAPs benefits. The opinions of interviewees were similar to the views reported by Brown and Pierce (2004) and Alabbadi and Areiqat (2010). The following comments illustrate interviewee affirmation of the non-usage of MAPs:

"We do not have confidence in management accounting practices values; there is ambiguity about the benefits of using management accounting practices" (Company D).

"In fact, management accounting tools are very complex. It is difficult to collect data on these practices, and it also takes a long time" (Company E).

\section{DISCUSSION}

The attained outcomes led to the deduction that the companies of most respondents made use of MAPs. Also, the findings of this study are consistent with several past related work in different countries including Hyvönen (2005) (Finland), Joshi (2001) (India), Chenhall and LangfieldSmith (1998) (Australia), and Ahmad, Leftesi (2014) (Libya) and Ahmad (2013) (Malaysia). Notably, some of these studies were carried out earlier but it appears that the usage rate of MAPs in some of these countries were higher compared to those in Jordan.

The rate of MAPs usage among Jordanian manufacturing SMEs are lower when compared to those in developed countries. Among the countries with fairly higher usage rates of MAPs include Australia (see Chenhall \& Langfield-Smith, 1998), New Zealand UK, and the U.S, (see Guilding et al., 2000), Finland (see Hyvönen, 2005), UK (see Abdel-Kader \& Luther, 2006), Slovenia (see Cadez \& Guilding, 2007), Finland and Greece (see Angelakis et al., 2010), and Greece (see Pavlatos \& Kostakis, 2015). However, when compared to the usage rate in developing countries such as Iran (see Ghasemi et al., 2015) and Malaysia (see Ahmad, 2013), the findings of this study 
are comparable. Interestingly, Ahmad and Leftesi (2014) reported lower usage rate of MAPs in Libya, which is an Arab country like Jordan, when compared to those reported in Jordan.

Based on the findings, some novel results on the utilization of MAPs by Jordanian manufacturing SMEs can be generated. In general, the use of basic techniques of management accounting has been common among Jordanian manufacturing SMEs, and among those commonly used include financial performance measures, costing systems, and budgeting systems. Among smaller firms especially, the preference towards the basic techniques of accounting and management accounting is expected. Also, considering that all respondents have their company operating in a developing country, lower usage of new management accounting tools (e.g., ABC, non-financial performance measures, and other modern techniques) can be expected. Similarly, Chun et al. (1996) examining firms in Singapore reported the preference towards the use of traditional management accounting systems in their external and internal reporting.

Relevant studies in developing countries have presented comparable findings as well. Among these studies include El-Ebaishi et al. (2003) (Saudi Arabia), Joshi (2001) (India), Ahmad and Leftesi (2014) (Libya) and Ahmad (2013) (Malaysia). Joshi (2001) for instance, found autocratic leadership, conservative attitude of Indian management, and long-term orientation as the reasons why new MAPs have low adoption rates among Indian firms. Among many Indian companies, there was a belief that the adoption of new management accounting techniques would be costly. Meanwhile, modern MAPs are increasingly being used among companies in developed countries with the traditional MAPs still retaining its popularity among most firms. Such situations have been reported in several studies (e.g., Abdel-Kader \& Luther, 2006; Chenhall \& Langfield-Smith, 1998; Pierce \& O’Dea, 1998).

The high usage of the traditional techniques has been linked to their more readily accessible related information and expertise (as opposed to those associated with modern management accounting techniques). Furthermore, uncertainties, practicality issues and costs associated with the implementation were found to be the factors of the low usage rates of the modern MAPs. Hence, a gap is present between the theoretical side and actual utilization of MAPs, particularly among manufacturing SMEs 
in Jordan. Similarly, Ashton et al. (1995), Drury et al. (1993) and Scapens (1985) also reported the presence of a gap between theoretical prescriptions in textbooks, and the real utilization of management accounting.

In general, the interviewees mentioned the use of variable cost, fixed cost, standard cost systems, and target cost, in generating pertinent information for strategic purposes, such as for reducing cost or for determining product price, to retain the organization's competitiveness in the market. The utilization of costing tools was also affirmed by the interviewees particularly in the determination of correct product cost information and in the prevention of gaining inaccurate product cost information as the outcome, considering that such information may impact decision-making, selling prices, and budget preparation. A similar finding was equally reported in Chenhall (2005) and Kaplan and Cooper (1998). As highlighted in these studies, the adoption of cost practices in the formation of information pertinent for strategic purposes would include product planning which encompasses product pricing, and for managerial purposes, cost reduction would be included.

The interviewees highlighted the significance of budgets practice. According to them, budgets encompass financial plans which furnish information for planning and controlling, and also for finding out problems. Budgets have been regarded as very important for the respondent companies especially for financial planning and for controlling the costs and expenses as well. Similarly, Chenhall and Langfield-Smith (1998), Joshi (2001), Tsamenyi et al. (2004) and Uyar and Kuzey (2016) reported that the use of various MAPs can lead to better performance of subunits and also better overall performance, which is attainable via financial control, planning, and controlling of operations, through the prudent utilization of business resources, and value creation.

Many advantages have been linked to the use of financial measures. For instance, the measures can determine whether or not the period outcomes are as projected. In addition, the measures are useful in making predictions on the risks surrounding the company to assure the efficiency of the company's performance. Performance measurement is, therefore, a vital tool for assessing the efforts of employees and for the customization of management bonuses. This finding supports the perspectives of Chenhall and Langfield-Smith (1998) and Hyvönen (2005). 
This study found that the respondent companies employed decision support tools for different purposes, and among them include price modification, new product release, expansion process, and potential risks estimation, through financial returns and product profitability analysis. The use of product profitability analyses has been common among manufacturing SMEs to eradicate the financially unfeasible products. Similarly, the respondent companies assert the significance of return on investment and payback period as both furnish them with the required information when new projects and investment expansion are being evaluated. These findings lend support to those of Abdel-Kader and Luther (2006).

The traditional management accounting tools are still relevant among the respondent companies. This is evidenced by their utilization of traditional budgets in their financial planning, control and evaluation of performance. Timetables are employed by these companies in the performance of certain programs and plans. Direct cost tools have also been used in product cost information determination. Also, the respondent companies employed financial measures in the computation of annual financial returns. Nonetheless, the use of traditional management accounting tools can be challenging, particularly in terms of product cost adjustments and in price fluctuations and consumer behaviour understanding. Still, among Jordanian manufacturing SMEs, the traditional management accounting tools remain integral, and arguably due to the tools' perceived benefits, their usage is expected to remain popular in the future.

The benefits of MAPs are undeniable particularly in improving the subunits and overall performance of organizations by way of financial control, planning and controlling of operations with the economical utilization of business resources, in addition to value creation as equally indicated in Horngren (2009) and Uyar and Kuzey (2016).

As presumed by the pro-innovation standpoint, innovations benefit the organizations that adopt and use them (Rogers, 1995). Based on this standpoint, if innovations are beneficial to the adopter, they will diffuse throughout the industry, but when innovations are not beneficial to the adopter, they will be rejected. Comparatively, innovations that are deemed inefficient will never be adopted while those that are deemed efficient will not face rejection. 
The works of Shields (1995) and Krumwiede (1998) acknowledged the creation of management accounting tools as a practical solution for issues associated with traditional systems. The use of these tools, as noted by the authors, will lead to the creation of accounting information that is more comprehensive and accurate. In the same context, Chung et al. (1997) claimed that the problems associated with the cost system currently being applied greatly motivate companies to employ MAPs. This was also affirmed by interviewees in this study, in that flaws in the traditional system are a motivator for MAPs usage. Experiments conducted in the past on leading companies that show the benefits of MAPs usage were another motivator. In this regard, it is possible for organizations to be inclined towards the adoption of modern practices such as MAPs due to their effectiveness and to emulate competitors.

As suggested by interview outcomes, both organizational and external reasons significantly contributed to MAPs diffusion. Specifically, high environmental uncertainty compels organizations to take in a substantial amount of financial and non-financial information (Gordon \& Miller, 1976). This perspective is in line with the Contingency Theory (see, Otley, 1980; Chenhall, 2003). This is also in line with results from Chapman (1997), Hoque (2005), Abdel-Kader and Luther (2008), and Cadez and Guilding (2008), who highlighted the vital role of accounting within each confronted level of uncertainty. The interview outcomes also denote a competitive environment forcing companies to employ MAPs. This further supports the findings by Mohamad et al. (2015).

Henderson and Venkatraman (1993) stated that managerial practices are consistent with strategic organizational priorities. Interview outcomes affirmed that company strategies have forced companies to employ specific techniques to obtain information that is both accurate and comprehensive for performance measurement. It was apparent from the interviews that when a company is equipped with advanced technology and a complicated production process more advanced and precise tools are used. Shank (1996) and Cadez and Guilding (2012) agree with this outcome by indicating the benefits offered by MAPs to an organization's strategy.

As demonstrated by interview outcomes, the non-use of MAPs is linked to many factors. First is insufficient knowledge. In particular, when 
top management staff has insufficient knowledge about MAPs, they tend not to adopt MAPs. Likewise, insufficient skills and experiences of accountants about the modern MAPs will force an organization to reject any new technique. Byrne (2011) supports this finding. Furthermore, interviewees mentioned that a possible reason for a lack of knowledge may be due to the accounting education system in Jordan, which still relies on traditional methods of learning. Therefore, managers and decision-makers in SMEs should rely on the heads of accounting departments, and accountants who have sufficient knowledge about MAPs. This could be achieved by employing holders of professional certificates, as well as stimulating current employees to obtain these certificates.

Support from top management is a key factor affecting the use of management accounting (Shields, 1995; Naranjo-Gil \& Hartmann, 2006; Intakhan, 2014). Being a critical factor to MAPs use, top management makes available the time, software, training programs, and resources for implementing management accounting tools (Gunasekaran, 1999; Askarany \& Smith, 2004; Maelah \& Ibrahim, 2006; Intakhan, 2014). Interview findings affirm a lack of management support in MAPs use. There also appears to be careless spending on MAPs.

Lack of financial resources is also causes non-usage of MAPs. As demonstrated by the interview findings, the financial status of the companies makes them unable to implement MAPs. This is supported by the findings of Wang (2014), Kim et al. (2016), and Madrid-Guijarro et al. (2016), who indicated that financial accessibility constraints are a significant factor negatively affecting innovation. In this regard, Otley (1980) and Ittner et al. (2003) mentioned that environmental and organizational factors influence the use of management accounting. Interviewees also confirmed the high costs linked with MAPs implementation as a key reason for not using these systems. Cohen et al. (2005) also share this view. According to them, the high cost of system implementation and consulting companies greatly contributes to challenges in ABC usage. Thus, MAPs characteristics, such as cost and complexity, are also considered a reason for not using MAPs.

The interviewees further added that companies have no urgent requirement for MAPs usage, which emphasizes the role of the demand side perspective in MAPs diffusion. The interviewees shared views similar 
to those documented in the management accounting literature. In this regard, Yazdifar and Askarany (2009) and Duh et al. (2009) pointed to the presence of certain companies that were not using modern accounting systems because the traditional systems currently in use were sufficient. The interview findings also affirmed the non-usage of MAPs as being caused by disadvantages related to the system itself, and ambiguities in terms of MAPs benefits. Brown and Pierce (2004) and Alabbadi and Areiqat (2010) also documented the same findings. Therefore, the interview findings affirm the perspective of the Contingency Theory, which asserted that environmental and organizational factors influence the use of MAPs (Otley, 1980; Chenhall, 2003; Ittner et al., 2003).

\section{CONCLUSIONS AND RECOMMENDATION}

Among Jordanian SMEs, the rate of MAPs usage appears to be comparatively low when compared to those reported in developed countries. On the other hand, MAPs usage rate among Jordanian SMEs are comparable to those reported in developing countries. SMEs employ MAPs mainly to generate information on product cost, in planning and controlling, in finding out problems, in assessing the efforts of employees, as well as in customizing management bonuses. Equally, MAPs have been used in forming the pertinent information in making decisions in the process of expansion, in the release of new products, in the modification and appraisal of prices, as well as in the projection of possible risks. As the benefits of MAPs are countless, firms should vigorously adopt them. Furthermore, there should be more effort undertaken by the government in Jordan in promoting the use of MAPs, such as the offering of tax exemptions as an incentive.

Shortcomings of the traditional system, previous experiments of large companies, organizational and external factors are considered as the main reasons that motivated SMEs to use MAPs. The findings indicate that insufficient MAPs knowledge, insufficient MAPs experience amongst accountants, negligent spending on MAPs, a lack of financial resources, and the high costs associated with implementing MAPs are considered the most crucial reasons that forced SMEs to neglected use a lot of MAPs. Considering the various factors, managers and decision-makers should consider these when making their decisions. 
Knowledge associated with MAPs within SMEs in the developed countries is presented in this study. As can be observed, MAPs studies in the context of small firms would be of value. Moreover, studies that covered this subject only reported the adoption rates of MAPs, while only a handful addressed the purpose of using MAPs. Notably, the presentation of statistical description and the interview analysis in the present study has enriched knowledge related to MAPs usage within the Jordanian setting. In other words, this study positively adds to the awareness among managers of SMEs concerning the worth of MAPs. Equally, scholars in developing countries can peruse the outcomes of this study in their examination of the SMEs sector. In the context of Jordan, the present study should encourage more scrutiny of MAPs among SMEs.

Considering that the employed sample was limited to Jordanian manufacturing SMEs, to generalize the outcomes of this study to other organizations in other industries is, therefore, inappropriate. It may be fruitful to consider other sectors as well, such as the service sector, and have their outcomes compared, as this may increase the generalizability of the results.

\section{ACKNOWLEDGEMENTS}

The present research makes up a component of the $\mathrm{PhD}$ thesis presented to Universiti Malaysia Terengganu under the following title: "A Contingency Perspective on Usage and Implications of MAPs and Organizational Performance: Evidence from Jordanian SMEs.”

\section{REFERENCES}

Abdel-Kader, M., \& Luther, R. (2006). Management accounting practices in the British food and drinks industry. British Food Journal, 108(5), 336-357.

Abdel-Kader, M., \& Luther, R. (2008). The impact of firm characteristics on management accounting practices: A UK-based empirical analysis. The British Accounting Review, 40(1), 2-27. 
Abdel-Maksoud, A., Abdallah, W., \& Youssef, M. (2012). An empirical study of the influence of intensity of competition on the deployment of contemporary management accounting practices and managerial techniques in Egyptian firms. Journal of Economic and Administrative Sciences, 28(2), 84-97.

Abrahamson, E. (1991). Managerial fads and fashions: The diffusion and rejection of innovations. Academy of Management Review, 16(3), 586-612.

AbRahman, N. A., Omar, N., Rashid, N. M. N. N. M., \& Ramli, A. (2016). Improving employees accountability and firm performance through management accounting practices. Procedia Economics and Finance, $35,92-98$.

Ahmad, K. (2013). The adoption of management accounting practices in Malaysian small and medium-sized enterprises. Asian Social Science, 10(2), 236-249.

Ahmad, K. (2017). The implementation of management accounting practices and its relationship with performance in small and medium enterprises. International Review of Management and Marketing, 7(1), 342-353.

Ahmad, N. S. M., \& Leftesi, A. (2014). An exploratory study of the level of sophistication of management accounting practices in Libyan manufacturing companies. International Journal of Business and Management, 2(2), 1-10.

Alabbadi, H., \& Areiqat, A. (2010). The systematic relationship between the activity based management (ABM) and the activity based costing (ABC). Interdisciplinary Journal of Contemporary Research in Business, 2(2), 239-264.

Angelakis, G., Theriou, N., \& Floropoulos, I. (2010). Adoption and benefits of management accounting practices: Evidence from Greece and Finland. Advances in Accounting, 26(1), 87-96.

Armitage, H. M., Webb, A., \& Glynn, J. (2016). The use of management accounting techniques by small and medium-sized enterprises: A field 
study of Canadian and Australian practice. Accounting Perspectives, 15(1), 31-69.

Ashton, D., Hopper, T., \& Scapens, R. (1995). The changing nature of issues in management accounting. In D. Ashton, T. Hopper, \& R. Scapens (Eds.), Issues in management accounting (pp. 1-20). Hertfordshire: Prentice Hall.

Askarany, D., \& Smith, M. (2003). The relationship between technological innovation, activity based costing and business size. Paper presented at the Information Science +Information Technology Education Joint Conference, Pori, Finland.

Askarany, D., \& Smith, M. (2004). Contextual factors and administrative changes. Journal of Issues in Informing Science and Information Technology, 1, 179-188.

Atkinson, A. A., Balakrishnan, R., Booth, P., \& Cote, J. M. (1997). New directions in management accounting research. Journal of Management Accounting Research, 9, 79-108.

Azudin, A., \& Mansor, N. (2018). Management accounting practices of SMEs: The impact of organizational DNA, business potential and operational technology. Asia Pacific Management Review, 23(3), 222226.

Bergamin Barbato, M., Collini, P., \& Quagli, A. (1996). Management accounting in Italy: Evolution within tradition. In A. Bhimani (Ed.), Management accounting - European perspectives (pp. 140-163). Oxford University Press.

Bjørnenak, T. (1997). Diffusion and accounting: The case of ABC in Norway. Management Accounting Research, 8(1), 3-17.

Boyatzis, R. E. (1998). Transforming qualitative information: Thematic analysis and code development. SAGE.

Braun, V., \& Clarke, V. (2006). Using thematic analysis in psychology. Qualitative Research in Psychology, 3(2), 77-101. 
Brierley, J. A., Cowton, C. J., \& Drury, C. (2001). Research into product costing practice: A European perspective. European Accounting Review, 10(2), 215-256.

Brown, R., \& Pierce, B. (2004). An empirical study of activity-based systems in Ireland. The Irish Accounting Review, 11(1), 55-61.

Bruque, S., \& Moyano, J. (2007). Organisational determinants of information technology adoption and implementation in SMEs: The case of family and cooperative firms. Technovation, 27(5), 241-253.

Byrne, S. (2011). What determines ABC success in mature sites? Journal of Accounting \& Organizational Change, 7(3), 259-277.

Cadez, S., \& Guilding, C. (2007). Benchmarking the incidence of strategic management accounting in Slovenia. Journal of Accounting \& Organizational Change, 3(2), 126-146.

Cadez, S., \& Guilding, C. (2008). An exploratory investigation of an integrated contingency model of strategic management accounting. Accounting, Organizations and Society, 33(7-8), 836-863.

Cadez, S., \& Guilding, C. (2012). Strategy, strategic management accounting and performance: A configurational analysis. Industrial Management \& Data Systems, 112(3), 484-501.

Chapman, C. S. (1997). Reflections on a contingent view of accounting. Accounting, Organizations and Society, 22(2), 189-205.

Chenhall, R. H. (2005). Integrative strategic performance measurement systems, strategic alignment of manufacturing, learning and strategic outcomes: An exploratory study. Accounting, Organizations and Society, 30(5), 395-422.

Chenhall, R. H., \& Langfield-Smith, K. (1998). Adoption and benefits of management accounting practices: An Australian study. Management Accounting Research, 9(1), 1-19. 
Chenhall, R. H., \& Langfield-Smith, K. I. M. (1999). The implementation of innovative management accounting systems. Australian Accounting Review, 9(19), 37-46.

Chua, W. F., \& Petty, R. (1999). Mimicry, director interlocks, and the interorganizational diffusion of a quality strategy: A note. Journal of Management Accounting Research, 11, 93-104.

Chun, L. S., Kassim, N. A. H., \& Minai, B. (1996). Are management accounting systems in Malaysia outmoded. Singapore Management Review, 18(1), 55-67.

Chung, L. H., Schoch, H. P., \& Teoh, H. Y. (1997). Activity-based costing in Singapore: A synthesis of evidence and evaluation. Accounting Research Journal, 10(2), 125-141.

Cohen, S., Venieris, G., \& Kaimenaki, E. (2005). ABC: Adopters, supporters, deniers and unawares. Managerial Auditing Journal, 20(9), 981-1000.

Creswell, J. W. (2013). Research design: Qualitative, quantitative, and mixed methods approaches. Sage Publications.

Damanpour, F. (1991). Organizational innovation: A meta-analysis of effects of determinants and moderators. Academy of Management Journal, 34(3), 555-590.

Davis, G. F., \& Marquis, C. (2005). Prospects for organization theory in the early twenty-first century: Institutional fields and mechanisms. Organization Science, 16(4), 332-343.

DiMaggio, P., \& Powell, W. W. (1983). The iron cage revisited: Collective rationality and institutional isomorphism in organizational fields. American Sociological Review, 48(2), 147-160.

Dogan, E., Islam, M. Q., \& Yazici, M. (2017). Firm size and job creation: Evidence from Turkey. Economic Research - Ekonomska Istraživanja, 30(1), 349-367. 
Drury, C., Braund, S., Osborne, P., \& Tayles, M. (1993). A survey of management accounting practices in UK manufacturing companies. Research Occasional Paper. London: Chartered Association of Certified Accountants (ACCA).

Duh, R.-R., Lin, T. W., Wang, W.-Y., \& Huang, C.-H. (2009). The design and implementation of Activity-Based Costing: A case study of a Taiwanese textile company. International Journal of Accounting \& Information Management, 17(1), 27-52.

El-Ebaishi, M., Karbhari, Y., \& Naser, K. (2003). Empirical evidence on the use of management accounting techniques in a sample of Saudi manufacturing companies. International Journal of Commerce and Management, 13(2), 74-101.

Frezatti, F. (2007). The "economic paradigm" in management accounting: Return on equity and the use of various management accounting artifacts in a Brazilian context. Managerial Auditing Journal, 22(5), 514-532.

Gehrke, I., \& Horvath, R. (2001). Implementation of performance measurement: A comparative study of French and German organizations. In M. J. Epstein \& J. F. Manzoni (Eds.), Performance measurement and management control: A compendium of research, studies in financial and management accounting (pp. 159-180). JAI Press.

Ghasemi, R., Mohamad, N. A., Mohammadi, M. A. D., \& bin Ali Khan, M. N. A. (2015). The diffusion of management accounting practices in Iranian manufacturing companies. Middle-East Journal of Scientific Research, 23(3), 394-404.

Giannetti, R., Marelli, A., \& Miolo Vitali, P. (2002). A survey on nonfinancial measure practices in Italian management accounting systems. Paper presented at the 25th Annual Congress of the European Accounting Association, Copenhagen, Denmark.

Gill, P., Stewart, K., Treasure, E., \& Chadwick, B. (2008). Methods of data collection in qualitative research: Interviews and focus groups. British Dental Journal, 204(6), 291-295. 
Gordon, L. A., \& Miller, D. (1976). A contingency framework for the design of accounting information systems. Accounting, Organizations and Society, 1(1), 59-69.

Guilding, C., Cravens, K. S., \& Tayles, M. (2000). An international comparison of strategic management accounting practices. Management Accounting Research, 11(1), 113-135.

Gunasekaran, A. (1999). A framework for the design and audit of an activitybased costing system. Managerial Auditing Journal, 14(3), 118-127.

Günerergin, M., Penbek, Ş., \& Zaptçıŏlu, D. (2012). Exploring the problems and advantages of Turkish SMEs for sustainability. ProcediaSocial and Behavioral Sciences, 58, 244-251.

Hage, J. (1980). Theories of organizations: Form, process, and transformation. John Wiley \& Sons.

Hage, J. T. (1999). Organizational innovation and organizational change. Annual Review of Sociology, 25(1), 597-622.

Haunschild, P. R., \& Miner, A. S. (1997). Modes of interorganizational imitation: The effects of outcome salience and uncertainty. Administrative Science Quarterly, 472-500.

Hoque, Z. (2005). Linking environmental uncertainty to non-financial performance measures and performance: A research note. The British Accounting Review, 37(4), 471-481.

Horngren, C. T. (2009). Cost accounting: A managerial emphasis (13th ed.). Pearson Prentice Hall.

Hyvönen, J. (2005). Adoption and benefits of management accounting systems: Evidence from Finland and Australia. Advances in International Accounting, 18, 97-120.

Intakhan, P. (2014). Direct \& indirect effects of top management support on ABC implementation success: Evidence from ISO 9000 certified 
companies in Thailand. Procedia-Social and Behavioral Sciences, 164, 458-470.

Ittner, \& Larcker, D. (2002). Empirical managerial accounting research: Are we just describing management consulting practice? European Accounting Review, 11(4), 787-794.

Ittner, C. D., Larcker, D. F., \& Randall, T. (2003). Performance implications of strategic performance measurement in financial services firms. Accounting, Organizations and Society, 28(7-8), 715-741.

Jarrar, N. S., \& Smith, M. (2014). Innovation in entrepreneurial organisations: A platform for contemporary management change and a value creator. The British Accounting Review, 46(1), 60-76.

JCI. (2015). Jordan Chamber of Industry. Retrieved from http://www.jci. org.jo/Pages/viewpage.aspx?pageID=175.

Joshi, P. L. (2001). The international diffusion of new management accounting practices: The case of India. Journal of International Accounting, Auditing and Taxation, 10(1), 85-109.

Joshi, P. L., Bremser, W. G., Deshmukh, A., \& Kumar, R. (2011). Diffusion of management accounting practices in gulf cooperation council countries. Accounting Perspectives, 10(1), 23-53.

Kaplan, R. S., \& Cooper, R. (1998). Cost \& effect: Using integrated cost systems to drive profitability and performance. Harvard Business Press.

Kaplan, R. S., \& Johnson, H. T. (1987). Relevance lost: The rise and fall of management accounting. Harvard Business School.

Kim, D. H., Lin, S. C., \& Chen, T. C. (2016). Financial structure, firm size and industry growth. International Review of Economics \& Finance, 41, 23-39.

Krumwiede, K. R. (1998). The implementation stages of activity-based costing and the impact of contextual and organizational factors. Journal of Management Accounting Research, 10, 239-277. 
Lachmann, M., Knauer, T., \& Trapp, R. (2013). Strategic management accounting practices in hospitals: Empirical evidence on their dissemination under competitive market environments. Journal of Accounting \& Organizational Change, 9(3), 336-369.

Langfield-Smith, K., Smith, D., Andon, P., Hilton, R., \& Thorne, H. (2017). Management accounting: Information for creating and managing value (8th ed.). McGraw-Hill Education Australia.

Lee, N., Sameen, H., \& Cowling, M. (2015). Access to finance for innovative SMEs since the financial crisis. Research Policy, 44(2), 370-380.

Macinati, M. S., \& Anessi-Pessina, E. (2014). Management accounting use and financial performance in public health-care organisations: Evidence from the Italian National Health Service. Health Policy, 117(1), 98-111.

Madrid-Guijarro, A., García, D., \& Van Auken, H. (2016). Financing constraints and SME innovation during economic crises. Academia Revista Latinoamericana de Administración, 29(1), 84-106.

Maelah, R., \& Ibrahim, D. N. (2006). Activity based costing (ABC) adoption among manufacturing organizations - The case of Malaysia. International Journal of Business and Society, 7(1), 70-101.

Mitchell, F., \& Reid, G. C. (2000). Editorial. Problems, challenges and opportunities: The small business as a setting for management accounting research. Management Accounting Research, 11(4), 385390.

Mohamad, N. A., Karami, M., Bajuri, N. H., \& Asgharizade, E. (2015). The relationship among strategy, competition and management accounting systems on organizational performance. European Online Journal of Natural and Social Sciences, 4(3), 565-581.

Naranjo-Gil, D., \& Hartmann, F. (2006). How top management teams use management accounting systems to implement strategy. Journal of Management Accounting Research, 18(1), 21-53. 
Newell, S., Robertson, M., \& Swan, J. (2001). Management fads and fashions. Organization, 8(1), 5-15.

Nuhu, N. A., Baird, K., \& Bala Appuhamilage, A. (2017). The adoption and success of contemporary management accounting practices in the public sector. Asian Review of Accounting, 25(1), 106-126.

Okpara, J. O. (2011). Factors constraining the growth and survival of SMEs in Nigeria: Implications for poverty alleviation. Management Research Review, 34(2), 156-171.

Pavlatos, O., \& Kostakis, H. (2015). Management accounting practices before and during economic crisis: Evidence from Greece. Advances in Accounting, 31(1), 150-164.

Pavlatos, O., \& Paggios, I. (2008). Management accounting practices in the Greek hospitality industry. Managerial Auditing Journal, 24(1), 81-98.

Pierce, B., \& O'Dea, T. (1998). Management accounting practices in Ireland-the preparers' perspective (Research Paper Series, Series No. 34). Dublin City University Business School. http://doras.dcu.ie/2217/

Rogers, E. M. (1995). Diffusion of innovations (4th ed.). New York: Free Press.

Rogers, E. M. (2010). Diffusion of innovations. Simon and Schuster.

Saez-Torrecilla, A., Fernandez-Fernandez, A., Texeira-Quiros, J., \& Vaquera-Mosquero, M. (1996). Management accounting in Spain: Trends in thought and practice. Management Accounting: European Perspective, 3, 180-190.

Scapens, R. W. (1985). Management accounting: A review of contemporary developments. McMillan Education.

Scapens, R. W. (1994). Never mind the gap: Towards an institutional perspective on management accounting practice. Management Accounting Research, 5(3-4), 301-321. 
Scott, W. R. (1995). Introduction: Institutional theory and organizations. The institutional construction of organizations. Sage Publications.

Sekaran, U., \& Bougie, R. (2016). Research methods for business: A skill building approach. John Wiley \& Sons.

Shank, J. K. (1996). Analysing technology investments - From NPV to strategic cost management (SCM). Management Accounting Research, $7(2), 185-197$.

Shields, M. D. (1995). An empirical analysis of firms' implementation experiences with activity-based costing. Journal of Management Accounting Research, 7, 148-165.

Shields, M. D., Chow, C. W., Kato, Y., \& Nakagawa, Y. (1991). Management accounting practices in the US and Japan: Comparative survey findings and research implications. Journal of International Financial Management \& Accounting, 3(1), 61-77.

Sulaiman, M. b., Nazli Nik Ahmad, N., \& Alwi, N. (2004). Management accounting practices in selected Asian countries: A review of the literature. Managerial Auditing Journal, 19(4), 493-508.

Szychta, A. (2002). The scope of application of management accounting methods in Polish enterprises. Management Accounting Research, 13(4), 401-418.

Teddlie, C., \& Tashakkori, A. (2009). Foundations of mixed methods research: Integrating quantitative and qualitative approaches in the social and behavioral sciences. Sage Publications Inc.

Tolbert, P. S., \& Zucker, L. G. (1983). Institutional sources of change in the formal structure of organizations: The diffusion of civil service reform, 1880-1935. Administrative Science Quarterly, 28(1), 22-39.

Tsamenyi, M., Bennett, M., \& Black, J. (2004). Perceived purposes of budgets in organizations in a developing country: Field study from Ghana. Journal of African Business, 5(1), 73-92. 
Turner, M. J., Way, S. A., Hodari, D., \& Witteman, W. (2017). Hotel property performance: The role of strategic management accounting. International Journal of Hospitality Management, 63, 33-43.

Uyar, A., \& Kuzey, C. (2016). Does management accounting mediate the relationship between cost system design and performance? Advances in Accounting, 35, 170-176.

Van de Ven, A. H. (1986). Central problems in the management of innovation. Management Science, 32(5), 590-607.

Van de Ven, A. H., \& Poole, M. S. (1990). Methods for studying innovation development in the Minnesota Innovation Research Program. Organization Science, 1(3), 313-335.

Wang, J. (2014). R\&D activities in start-up firms: What can we learn from founding resources? Technology Analysis \& Strategic Management, 26(5), 517-529.

Wang, T., Thornhill, S., \& Zhao, B. (2018). Pay-for-performance, employee participation, and SME performance. Journal of Small Business Management, 56(3), 412-434.

Waweru, N. M., Hoque, Z., \& Uliana, E. (2004). Management accounting change in South Africa: Case studies from retail services. Accounting, Auditing \& Accountability Journal, 17(5), 675-704.

Wijewardena, H., \& De Zoysa, A. (1999). A comparative analysis of management accounting practices in Australia and Japan: An empirical investigation. The International Journal of Accounting, 34(1), 49-70.

Wu, J., Boateng, A., \& Drury, C. (2007). An analysis of the adoption, perceived benefits, and expected future emphasis of western management accounting practices in Chinese SOEs and JVs. The International Journal of Accounting, 42(2), 171-185.

Yazdifar, H., \& Askarany, D. (2009). A comparative investigation into the diffusion of management accounting innovations in the UK, Australia 
and New Zealand. Chartered Institute of Management Accountant (CIMA), 5(12), 1-11.

Zaltman, G., Duncan, R., \& Holbek, J. (1973). Innovations and organizations. Wiley New York.

Zammuto, R. F., \& O'Connor, E. J. (1992). Gaining advanced manufacturing technologies' benefits: The roles of organization design and culture. Academy of Management Review, 17(4), 701-728. 